\title{
Article \\ Short-Selling and Financial Performance of SMEs in China: The Mediating Role of CSR Performance
}

\author{
Wenzhen Mai * and Nik Intan Norhan binti Abdul Hamid
}

Citation: Mai, Wenzhen, and Nik Intan Norhan binti Abdul Hamid. 2021. Short-Selling and Financial Performance of SMEs in China: The Mediating Role of CSR Performance. International Journal of Financial Studies 9: 22. https:// doi.org/10.3390/ijfs9020022

Academic Editor: Frank Li

Received: 12 February 2021

Accepted: 9 April 2021

Published: 15 April 2021

Publisher's Note: MDPI stays neutral with regard to jurisdictional claims in published maps and institutional affiliations.

Copyright: (c) 2021 by the authors. Licensee MDPI, Basel, Switzerland. This article is an open access article distributed under the terms and conditions of the Creative Commons Attribution (CC BY) license (https:// creativecommons.org/licenses/by/ $4.0 /)$.
Azman Hashim International Business School, Universiti Teknologi Malaysia, Johor Bahru 81310, Malaysia; m-norhan@utm.my

* Correspondence: wenzhen@graduate.utm.my

\begin{abstract}
The aim of this study is to examine the effect of short-selling deregulation on the financial performance of SMEs in China. The external governance role of short-selling is also tested by adopting corporate social responsibility (CSR) performance as the mediating effect. This study investigates a panel data analysis with a sample of 5038 firm-years of SMEs listed in Shenzhen Stock Exchange from 2010 to 2019. The PSM-DID method is adopted in this study to alleviate self-selection and endogenous problems to observe the comparable pure effect of short-selling deregulation, while the mediation test is conducted based on Baron and Kenny's model. The finding of this study showed that the existence of short-selling could enhance firm financial performance and the mediating effect of CSR performance position in their relationship. In addition, the further analysis revealed that the mediating effect of CSR is more pronounced for family businesses and firms with high real short-selling threats. The robust test of alternative measurements is conducted and valid. This study provides insights for policymakers to consider further short-selling ban lifting and corporate executives to practice more CSR activities to improve the financial performance. Limitations and further implications of this study are also discussed.
\end{abstract}

Keywords: short-selling; CSR; SMEs; financial performance

\section{Introduction}

Although the short-selling mechanism has been available in developed markets for many years for pessimistic investors to profit from stock price declines, China's financial regulators only began loosening their short-selling restrictions in March 2010. This transformative reform of the capital market brought about a breakthrough in China's A-share market, ending the over 20-year history of its buy-only trading market. Empirical studies referring to short-selling have described short-sellers as sophisticated investors, who can identify overvalued stocks (Miller 1977), detect managers' misbehavior (Massa et al. 2015), reveal firms' real earnings management (Fang et al. 2016), improve environmental protection investment (Wang and Zhang 2020), and act as firms' external monitoring governance (Deng and Gao 2018). As such, assessing the economic implications of short-selling is important in financial analysis.

However, there remains no consensus on the justification of the short-selling mechanism (Jiang et al. 2020). In general, there are few scholars have drawn attention to the relationship between short-selling and the financial performance of the organization. The lack of in-depth research on the impact of short-selling may lead Chinese financial regulators to overlook the importance of this mechanism on financial performance. Thus, this paper will investigate the positive and significant relationship between short-selling and financial performance of small and medium enterprises (SMEs) in China. Besides short-selling, other aspects impact SME's performance, such as the economic aspects of SME activity, social issues (Cicea et al. 2019) and the willingness to implement industry 4.0 in SMEs (Michna and Kmieciak 2020) in China. 
In addition, corporate social responsibility (CSR) is an essential condition for the sustainable development of companies globally (Kiriu and Nozaki 2020). Consequently, policymakers have recognized the necessity to improve CSR performance to encourage sustainable development. In this regard, it is vital to consider the internal drives and external influences acting on a company's willingness to engage in environmental and social governance activities (Ali et al. 2017). A growing number of studies have a focus on the factors that influencing the companies' CSR behavior, including ownership structure (Lamb and Butler 2018; Velte 2020), political, social, and cultural characteristics (Ali et al. 2017), stock price reactions (Endrikat 2016), and ethical factors (Birindelli et al. 2015). The link between short-selling and CSR performance is examined in the US context (Gao and Julian 2018; Lu et al. 2016; Rusinova and Wernicke 2019). However, few Chinese related studies consider the capital market tools, such as short-selling, affect the motives of corporate sustainability.

Although limited previous studies focused on short-selling and CSR performance in China, some scholars empirically investigate the short-selling deregulation impacts on the individual components of social responsibility issues of firms. For environmental contributions, prior research has proven that short-selling affects corporate environment protection by increasing pollution-related investments (Wang and Zhang 2020). In terms of social issues, short-selling contributes to growing corporate philanthropy and donations (Hou et al. 2019). In relation to governance factors, short-selling prevents information leakage by shared directors across different companies (Cheng et al. 2019), improves the relationship between managers and employees (Brockman et al. 2020), enhances internal controls (Chen et al. 2019), and encourages board independence (Rahman et al. 2020). In addition, studies are examining the relationship between CSR performance and firm financial performance all over the world. Alshehhi et al. (2018) review 132 empirical studies from 2002 to 2017 and found that $78 \%$ of articles showed a positive relationship between sustainable corporate behaviors and firm financial performance. Furthermore, researchers in their studies (Deng and Cheng 2019; Li et al. 2019b; Rajesh and Rajendran 2020) revealed that the high engagement in CSR activities has a positive effect on firm financial performance. Thus, this study attempted to establish the role of short-selling in firm financial performance through the mediating channel of CSR performance, in addition to assessing alternative proxies in the robustness test.

Adopting novel panel data of 5038 firm-year observations on Chinese SMEs listed in the Shenzhen Stock Exchange from 2010 to 2019, this paper constructed a propensity score matching (PSM) and difference-in-differences (DID) model is to analyze whether the lifting of the short-selling ban has improved firm financial performance. The PSM method helped mitigate the self-selection problem of designated short-selling lists that were nonrandomly selected, while the DID method use to compare the pure effect of short-selling before and after the deregulation across other non-shortable companies. In addition, the three-step model proposed by Baron and Kenny (1986) was used to test the mediating effect of CSR performance. The results unfold that CSR is the full mediator for deregulation of shortselling to improve financial performance. Further analyses are conducted to unveil that the mediating effect of CSR is more pronounced for family businesses and firms with high real short-selling positions. The robust test is adopted to substitute CSR and financial performance by alternative proxies and confirms the above analysis.

The main contributions of this paper are three-fold. First, from the deterrence perspective, short-selling can prevent management misbehavior and agency problems, but the effectiveness of short-selling on firm financial performance remains inconclusive. Thus, this study will expand the existing literature by examining how the deregulation of short-selling in China affects firm value creation by adopting Tobin's $Q$ and return on assets (ROA) of listed SMEs as measures. Secondly, as SMEs in China implement social responsibility projects and engage in CSR activities to attract stakeholders' attention, this study will add value by considering CSR performance as the mediating aspect through which short-selling affects firm financial performance, specifically through the channels of refined environment protection, social responsibility, and corporate governance. Third, as per the Chinese finan- 
cial regulation authorities, short-selling deregulation only includes selected stocks rather than all stocks, which may lead to the self-selection problem (Li et al. 2017). Aiming to maintain the reliability of empirical results, this paper conducts PSM to compare shortable and non-shortable firms, which mitigated the issues of endogeneity and self-selection. Additionally, the DID approach was applied to examine the pure effect of short-selling deregulation on the firm financial performance of listed family businesses in China.

The next sections of this paper are organized as follows: The Literature Review section presents short-selling characteristics and SME Board development in China and the theoretical foundation and hypotheses development of this research. The Methodology section explains the study's data, methodology, and measures, while the Results section analyses the detailed empirical results of the study. The final section outlines the conclusions, implications, and limitations of this research.

\section{Literature Review}

\subsection{Short-Selling and the SME Board in China}

To improve the market efficiency and liquidity, in 2010, the CSRC implement a project for pilot firms to be on the designated list for short-selling by qualified investors. Since then, CSRC has gradually removed the bans on short-selling for stocks listed in China. In the first phase of deregulation, 90 companies were select from the Shanghai and Shenzhen Stock Exchanges to join the list of shortable stocks. By the end of 2019, a total of 1600 listed stocks in China were on the designated list, though some stocks had been removed from the list by the time. Due to the gradual inclusion of stocks to the designated list, the short-selling mechanism in China provides an unprecedented opportunity for research on the pure effect of the short-selling ban lift on firms by comparing their performance before and after they were included in the designated list as well as by comparing them with firms, not in the list.

However, the self-selection problem cannot be ignored when studying the short-selling mechanism, given that the Shanghai and Shenzhen Stock Exchanges require a shortable minimum of 4000 shareholders for a specific stock and a daily trading turnover rate that is $15 \%$ higher than the index turnover rate; (iii) minimum of 20 million outstanding shares or 800 million market capitalization; and (v) not a special treatment (ST) firm. Therefore, firms can only be included in the designated short-selling list if they meet the above requirements. Moreover, to protect the ordinary public, only qualified investors with more than 0.5 million yuan in securities assets and at least six months of trading experience are eligible to participate in short-selling trading activities. Thus, short-sellers in China typically have professional trading experience, high net assets, and access to public and private firm information; they are thus regarded as informed traders. Overall, the short-selling business has rapidly developed in China, making it crucial to understand the implications of shortselling activities for SMEs' social responsibility and financial performance.

The capital market in China was established in the 1990s by the Chinese government. According to security law, the initial public offering (IPO) market is controlled by the China Securities Regulatory Commission (CSRC). In the beginning, the Chinese capital market only served state-owned and large companies. Only a small number of SMEs could be listed in the capital market for IPO financing. However, in 2004, listing regulations were reform, and the objective is to provide opportunities to numerous SMEs to go public with the establishment of the SME Board. Although regulations remain strict in terms of firms' size and profitability, the Shenzhen Stock Exchange (SZSE) has built comprehensive SME stocks to meet the following conditions: (i) trade for at least three months after IPO; (ii) listing market to expand capital market diversity. As of early 2017, over 800 SMEs were listed on the SME Board, indicating that China is making efforts towards a multilayered capital market to support SME equity financing. 


\subsection{Short-Selling and Firm Financial Performance}

Following the theory of external governance, short-selling activities stimulate the detection of negative information and increase managers' cost of seeking private benefits, which is useful in restricting their unethical behaviors and moral hazards (Chen et al. 2020b; Li et al. 2019a; Mai and Hamid 2020; Rennekamp et al. 2019). For example, Chen et al. (2020b) suggest that relaxing short-selling constraints would reduce the risk of companies facing the agency problem and information opaqueness, thus lowering the borrowing costs and enhancing the firm value. This is because the potential adverse effect on stock prices places pressure on managers, thereby acting as an external supervision mechanism of corporate governance. In line with this, Rennekamp et al. (2019) found that with the threat of short-selling, managers are more likely to use real earnings management (REM) compared to accrual earnings management (EM) as a reporting method because REM operations are more appropriate and transparent and so are more useful in defending against short-sellers.

In addition, short-selling can mitigate the agency costs of corporate executives' managerial short-sightedness. Based on the agency theory, managers tend to take fewer risks in the long term and prefer to enjoy a quiet life. However, short-selling can pose a threat to their job security and reputation once short-sellers detect managerial myopia and short-sell a stock. Empirically, Li et al. (2019a) examine the governance effect of short-selling on corporate innovation among Chinese listed companies. They found that short-selling has a substantial positive impact on organizational innovation in terms of both the quantity and quality of innovation outputs, especially in companies with weaker corporate governance mechanisms. This can be explained by short-selling's ability to reduce firms' information asymmetry and improve the effectiveness of managerial compensation. Likewise, Mai and Hamid (2020) research on the effects of short-selling on firm financial performance in the Chinese pharmaceutical industry indicated that short-selling plays a deterrent role in corporate policies, such that shortable firms engage in fewer earnings management schemes and more productive R\&D investments. Conversely, Ni and Yin (2020) commented that companies have weaker short-run and long-run financial performance after the removal of short-sale bans, on the basis that shortable companies undertake less risk and suffer worse profitability as a result of decreases in capital expenditures, innovation investments, and external financing in light of growing short-sale threats.

Overall, the emergence of short-selling can deter the agency problem between shareholders and managers by aligning the aims of both parties towards confronting the potential threat of short-sellers. Based on the discussion above, this paper is inclined to hypothesize that the deregulation of short-selling improves firm financial performance, as postulated below:

Hypothesis 1 (H1). There is a positive relationship between short-selling deregulation and firm financial performance.

\subsection{Short-Selling, CSR Performance, and Firm Financial Performance}

It is essential to understand the role of short-selling in improving corporate sustainability and CSR performance. Ali et al. (2017) review of 76 empirical studies and the result of the study revealed that the CSR performance is significantly affected by a firm's internal characteristics, such as asset size, corporate governance mechanism, and profitability, as well as by external factors, such as politics, culture, and society.

To avoid the threat of short-selling behaviors, corporate managers would improve the CSR performance to demonstrate their long-term corporate sustainability strategies. Based on the empirical evidence on US SHO regulation, Gao and Julian (2018) proposed that managing executives adopt CSR to avoid adverse events, such as short-selling threats. Their results proved that firms with a high degree of short-selling attacks would adopt CSR as a public relation defense for the downside risk of stock price. Similarly, Rusinova and Wernicke (2019) contended that when firms are confronted with an increased threat of 
short-sellers attempting to affect the stock price, managing executives will increase their CSR performance to reduce risking the firm's stock price. The above studies present the link between short-selling and CSR in the US, whereby few studies have focused on their relationship in developing countries, such as China.

With respect to environmental protection as a component of CSR, Wang and Zhang (2020) found that corporate executives are likely to increase investments in pollution prevention and environmental protection due to fear of serious punishment by the Chinese government, which in turn would exert downward pressure on their stock price when short-sellers detect this negative information. Both government penalties and short-seller threats thus endanger managers' reputations and job positions. To avoid this unfavorable situation, managers prefer to appropriately practice environmental protection activities.

In terms of social responsibility in CSR performance, Hou et al. (2019) indicated that short-selling threats are the motivation for executives to conduct corporate philanthropy to remedy shortages and weaknesses in their corporate management so as to defend their short-selling positions. At least, in the short-term, corporate philanthropy can shift public attention to the positive side of companies.

In relation to the governance factor, Cheng et al. (2019) found that short-sellers tend to access possible business information leakage through the board member network, especially through shared directors of different companies. Therefore, the threat of shortselling can limit information leakage among insiders. Rahman et al. (2020) revealed that short-selling could improve board independence in the United States, given that such independence minimizes the agency problem, which draws the attention of shortsellers. Moreover, with short-selling, corporate executives are more concerned about employee relationships since disputes and scandals with employees can provide negative information for short-selling activities (Brockman et al. 2020). In China, Chen et al. (2019) demonstrated that short-selling positively affects the internal control of companies selected for the shortable list. This improvement is more obvious for companies with lower internal control requirements, such as non-government-owned businesses.

Besides the strong relationship between short-selling and individual CSR components, the literature revealed empirical evidence that high engagement in CSR activities has a positive effect on firm financial performance (Deng and Cheng 2019; Li et al. 2019b; Rajesh and Rajendran 2020). Rajesh and Rajendran (2020) found that CSR scores serve as an indicator of organizational sustainability performance on the relationship between sustainable practices and the financial performance of 1820 global companies. Li et al. (2019b) also researched 2613 firms internationally and found that firm executives strategically use both symbolic and substantive CSR to repair their reputation after corporate criticism, though symbolic CSR is more likely to be adopted in this case. Both CSR strategies can divert public attention and benefit firm performance, more so in countries defined by a high level of mutual trust. In China, Deng and Cheng (2019) confirmed that ESG metrics are positively correlated with stock price changes, especially in non-state-owned enterprises and the manufacturing industry. They also suggested that firms can achieve better sustainable financial performance by paying more attention to information availability, environmental protection, structural changes in CSR performance, and CSR engagement.

Based on the above discussion, we expect that where short-selling exists, managers are more disciplined, long-term oriented, and inclined to avoid self-interested behaviors. Thus, CSR performance is improved, resulting in higher firm financial performance. The following hypothesis was, therefore, postulated:

Hypothesis 2 (H2). CSR performance mediates the effect of short-selling deregulation on firm financial performance.

This paper tested the proposed relationships as per the framework shown in Figure 1. 


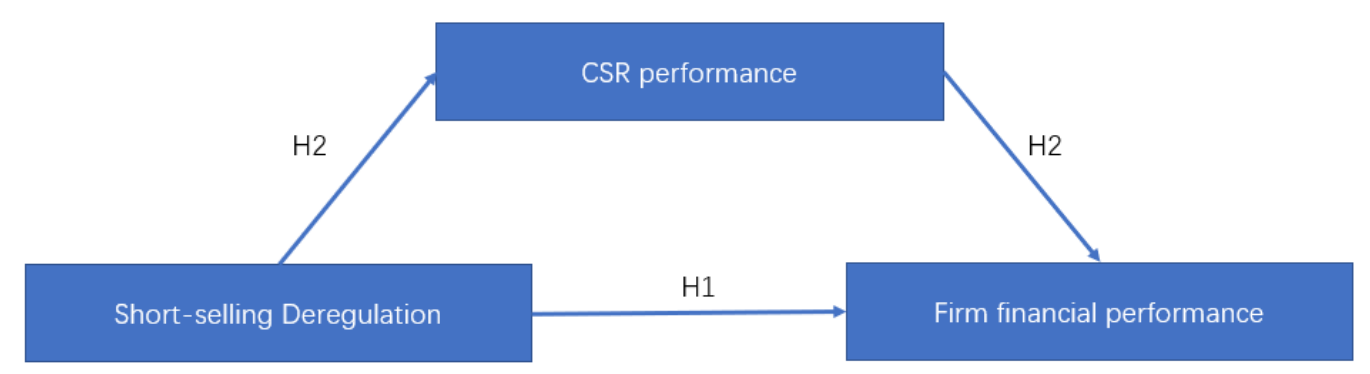

Figure 1. Research framework.

\section{Methodology}

\subsection{Measurements of Variables}

The main objective of this paper is to measure both deregulation of short-selling and the propensity of short sales. Following Park (2017); Fang et al. (2016); and Mai and Hamid (2020), SHORT $*$ TREAT is the variable to measure the deregulation of short-selling. While, SHORT is the variable of the short dummy, which is regarded as one if the stock is permitted for short-sale during the sample period and zero otherwise. TREAT is a time dummy, which equals one if the stock is shortable by the end of current fiscal year and zero otherwise. SHORT $*$ TREAT is thus the interactive item for the DID model, which ensured that firm financial performance is captured over the entire fiscal year either before or after the exogenous shock. All of the SHORT, TREAT and the interactive item, SHORT * TREAT, are used in the regression.

We adopted the actual annual CSR scores of individual stocks from 2010 to 2019 to proxy their CSR performance. Guided by Hu et al. (2018), we intended to collect the CSR score data from CSR rating reports issued by the Hexun Net CSR rating index in the Hexun Net database, where CSR indices are defined as actual CSR scores of firm's rating. Hexun Net is a professional evaluation system for the social responsibility of listed companies, which encompasses five categories, which are shareholder responsibility; employee responsibility; supplier, customer, and consumer rights responsibility. Environmental responsibility; and social responsibility. Each category has secondary and tertiary indicators to comprehensively assess social responsibility, comprising a total of 13 secondary indicators and 37 tertiary indicators. Additionally, industrial characteristics are accounted for in this evaluation as different weightings are specifically set for secondary and tertiary indicators.

To measure the value of the firm, this paper employed Tobin's $Q$ and ROA. Tobin's $\mathrm{Q}$ is appropriate for identifying firm performance in terms of the stock market and is calculated as the market value of total assets divided by asset value. ROA was adopted to account for the financial value of the firm, which is calculated as the net income divided by total assets.

In line with previous studies (Deng and Cheng 2019; Xu et al. 2020), this paper adopted several control variables to capture the fundamentals of SMEs. Firm size (SIZE) was calculated as the natural logarithm of market capitalization, firm growth (GROWTH) was computed as the market-to-book ratio, and leverage (LEV) was measured as total liability divided by total assets. Using year-effect (YEAR) and industry-effect (INDUSTRY), we used to address time- and industry-specific conditions that may play a role in the relationship between short-selling and firm financial performance. The definitions of the main variables are presented in Table 1. 
Table 1. Description and measurement of variables.

\begin{tabular}{|c|c|c|}
\hline Variable & Measurement & Source \\
\hline \multicolumn{3}{|c|}{ Independent variables } \\
\hline Deregulation of short-selling (SHORT) & $\begin{array}{l}\text { A dummy variable }(0,1) \text { equals } 1 \text { if the firm is } \\
\text { shortable and } 0 \text { otherwise }\end{array}$ & Shenzhen Stock Exchange \\
\hline Time factor of short-selling (TREAT) & $\begin{array}{c}\text { A dummy variable }(0,1) \text { equals } 1 \text { for the years after } \\
\text { the firm is shortable and } 0 \text { otherwise. }\end{array}$ & Shenzhen Stock Exchange \\
\hline SHORT * TREAT & Interactive item of SHORT and TREAT & Shenzhen Stock Exchange \\
\hline \multicolumn{3}{|c|}{ Mediating variable } \\
\hline CSR performance (CSR) & The actual CSR scores of individual stocks & Hexun Net CSR rating data \\
\hline \multicolumn{3}{|c|}{ Dependent variables } \\
\hline Tobin's Q & Market value of total assets divided by asset value & CSMAR Database \\
\hline ROA & Net income divided by total assets & CSMAR Database \\
\hline \multicolumn{3}{|c|}{ Control Variables } \\
\hline Firm size (SIZE) & Natural logarithm of market capitalization & CSMAR Database \\
\hline Firm growth (GROWTH) & Market-to-book ratio & CSMAR Database \\
\hline Firm leverage (LEV) & Total liability divided by total assets & CSMAR Database \\
\hline \multicolumn{3}{|c|}{ Year effect } \\
\hline \multicolumn{3}{|c|}{ Industry effect } \\
\hline
\end{tabular}

\subsection{Empirical Models}

In hypothesis 1, this paper explores whether the deregulation of short-selling has a positive impact on financial performance using model 1. Hypothesis 1 will be supported if the coefficients of SHORT and SHORT $*$ TREAT are positive and significant.

$\begin{aligned} \text { Tobin's } \mathrm{Q} & =\mathrm{a} 0+\mathrm{a} \text { SHORT }+\mathrm{a} \text { TREAT }+\mathrm{a} 3 \text { SHORT } * \text { TREAT }+\mathrm{a} 4 \text { controls }+\mathrm{a} \text { INDUSTRY }+\mathrm{a} 6 \text { YEAR }+\varepsilon \\ \text { ROA } & =\mathrm{a} 0+\mathrm{a} \text { SHHORT }+\mathrm{a} \text { TREAT }+\mathrm{a} \text { SSHORT } * \text { TREAT }+ \text { a4controls }+\mathrm{a} \text { INDUSTRY }+\mathrm{a} \text { YEAR }+\varepsilon\end{aligned}$

For hypothesis 2, this paper explores whether CSR performance mediates the relationship between the deregulation of short-selling and firm financial performance. The mediation analysis is based on the model suggested by Baron and Kenny (1986) to test in a three-step process. The first step, financial performance (dependent variable), is regressed on short-selling deregulation (independent variable), which is illustrated in model 1a and model $1 \mathrm{~b}$; the second step, CSR performance (mediator), is regressed on short-selling deregulation (independent variable), which is stated in model 2; the third step, financial performance (dependent variable) is regressed on short-selling deregulation (independent variable) and CSR performance (mediator), which is presented in model $3 \mathrm{a}$ and $3 \mathrm{~b}$.

Hypothesis 2 is supported if three requirements are met: First, the coefficient of the short-selling deregulation is positive and significant in model 1) and model 2; second, the coefficient of the CSR performance (mediator) is positive and significant in model 3; third, the effect of the coefficient of the short-selling deregulation (independent variable) is lower in model 3 than in model 1.

$$
\mathrm{CSR}=\mathrm{a} 0+\mathrm{a} \text { SHORT }+\mathrm{a} 2 \mathrm{TREAT}+\mathrm{a} 3 \mathrm{SHORT} * \mathrm{TREAT}+\mathrm{a} 4 \text { controls }+\mathrm{a} \text { INDUSTRY }+\mathrm{a} \text { YYEAR }+\varepsilon
$$

Tobin's $\mathrm{Q}=\mathrm{a} 0+\mathrm{a}$ SHORT $+\mathrm{a}$ 2TREAT $+\mathrm{a} 3$ SHORT $*$ TREAT $+\mathrm{a} 4 \mathrm{CSR}+\mathrm{a}$ controls $+\mathrm{a}$ INDUSTRY $+\mathrm{a}$ YYEAR $+\varepsilon$

ROA $=\mathrm{a} 0+\mathrm{a} 1 \mathrm{SHORT}+\mathrm{a}$ TREAT $+\mathrm{a} 3$ SHORT $*$ TREAT $+\mathrm{a} 4$ CSR $+\mathrm{a} 5$ controls $+\mathrm{a}$ INDUSTRY $+\mathrm{a}$ YYEAR $+\varepsilon$

\subsection{The Propensity Score Matching (PSM) Method}

Rather than being randomly picked from the developed market, the shortable list of pilot stocks in China was selected in this study based on the specific standards and unique 
characteristics of listed SMEs in the Shenzhen stock exchange (He and Tian 2016). To avoid the problem of self-selection from this circumstance, this paper attempted to use the PSM method to build an experimental group (companies in the short-sale list) and a control group (companies not in the short-sale list) with no significant differences in company characteristics to estimate the main specific models.

Based on the guidance by Caliendo and Kopeinig (2008), this paper performs the following procedure to employ the PSM method. First, we use the characteristics of shortable firms, including firm size, growth, and leverage, as the experimental dataset and nonshortable firms as the matching sample. Second, we apply a logit model for the propensity score estimation in which the dependent variable was experimental. Additionally, the nearest neighbor matching strategy was conducted to achieve the closest propensity score (i.e., within 0.01 ) to match each experimental firm with a control firm. With this method, all pairs were retained in the multiple matching exercise. The year and industry fixed effects were considered in the model as well.

After the matching, we get in a total of 2519 pairs of firm-year observations in treatment and control groups. Table 2 presents the summary statistics of the after-matching treatment and control firms. It is shown that after PSM matching, the two groups of firms have no significant differences regarding firm characteristics, representing that the self-selection problem is mitigated as the two groups are comparable.

Table 2. Statistics of the samples after the propensity score matching (PSM) method.

\begin{tabular}{ccccccccc}
\hline & \multicolumn{3}{c}{ Treatment Group (Shortable) } & \multicolumn{3}{c}{ Control Group (Non-Shortable) } \\
\hline Variables & N & Mean & Std & Median & N & Mean & Std & Median \\
\hline Tobin's Q & 2519 & 2.1173 & 1.0901 & 1.7596 & 2519 & 2.1435 & 1.0057 & 1.8221 \\
ROA & 2519 & 0.0596 & 0.0455 & 0.0528 & 2519 & 0.0580 & 0.0461 & 0.0545 \\
CSR & 2519 & 24.6204 & 14.1353 & 22.0800 & 2519 & 25.9472 & 15.6520 & 22.8500 \\
SIZE & 2519 & 22.8171 & 0.8156 & 22.7828 & 2519 & 22.7885 & 0.7553 & 22.7858 \\
GROWTH & 2519 & 0.0501 & 0.0351 & 0.0392 & 2519 & 0.0449 & 0.0302 & 0.0361 \\
LEV & 2519 & 0.3717 & 0.1799 & 0.3572 & 2519 & 0.3837 & 0.1725 & 0.3795 \\
\hline
\end{tabular}

\subsection{Data and Sample Sources}

This paper uses data from a sample of Chinese A-share listed SMEs in the SME Board of the Shenzhen stock exchange from 2010 to 2019. The data for short-selling volume and financial performance were sourced from the China Stock Market and Accounting Research Database (CSMAR). CSR performance scores were taken from the Hexun Net database, whereas the short-sale list data were acquired from the Shenzhen Stock Exchange website. We began the analysis in 2010 because the first stage of short-selling deregulation started in March 2010, while data on CSR performance was available since 2010. As such, starting from 2010 ensured that the short-selling constraint was sufficiently relaxed and CSR data were available for our sample.

Following the common practice in developed countries (Massa et al. 2015) and China (Chen et al. 2020a), financial firms, ST firms, firms that were previously shortable but later became non-shortable, and firms with missing related information were excluded from this research. This paper also limited the data at the $1 \%$ and $99 \%$ levels to mitigate the effects of outliers. With these conditions, a preliminary sample was obtained from 836 firms in Shenzhen Stock Exchange's SME Board with 5038 firm-years, including 311 firms in the designated list of short-selling and 525 firms out of the shortable list of firms. The distribution of the sample by industry is shown in Table 3. 
Table 3. Distribution of sample by industry.

\begin{tabular}{|c|c|c|c|}
\hline Industry & $\begin{array}{l}\text { Total } \\
\text { Firms }\end{array}$ & $\begin{array}{l}\text { Shortable } \\
\text { Firms }\end{array}$ & $\begin{array}{l}\text { Non-Shortable } \\
\text { Firms }\end{array}$ \\
\hline Manufacturing & 640 & 235 & 405 \\
\hline Leasing and commercial services & 14 & 5 & 9 \\
\hline Civil engineering & 7 & 1 & 6 \\
\hline Real estate & 9 & 4 & 5 \\
\hline Wholesale and retail trade & 23 & 14 & 9 \\
\hline Infrastructure & 8 & 1 & 7 \\
\hline Transport and postal services & 13 & 2 & 11 \\
\hline Animal husbandry & 11 & 4 & 7 \\
\hline Healthcare & 3 & 1 & 2 \\
\hline Construction & 30 & 10 & 20 \\
\hline Software and information technology services & 53 & 30 & 23 \\
\hline Internet and related services & 10 & 0 & 10 \\
\hline Mining and washing of coal & 6 & 3 & 3 \\
\hline Hospitality & 1 & 0 & 1 \\
\hline Culture, sports and arts & 5 & 0 & 5 \\
\hline Education & 3 & 1 & 2 \\
\hline Total & 836 & 311 & 525 \\
\hline
\end{tabular}

Source: Shenzhen Stock Exchange.

\section{Results and Discussion}

\subsection{Empirical Results}

Table 4 shows the descriptive statistics of variables in this research. It is presented that the mean value of financial performance, proxied by Tobin's Q and ROA, is 2.1304 and 0.059. After the PSM method, the mean value of shortable firms is 0.509 , close to $50 \%$ of the observations, while the mean value of SHORT * TREAT is 0.217 , meaning that $21.7 \%$ of observations are shortable with that year. CSR scores have a mean value of 25.284 with the highest score of 89.010 and the lowest score of -16.72 , which is consistent with the results of Hu et al. (2018) and indicates that the CSR performance of Chinese listed companies is weak. Regarding the control variables, the average firm size, growth and leverage are 22.803, 0.047 and 0.3777 .

Table 4. Descriptive statistics of variables.

\begin{tabular}{cccccc}
\hline Variables & Samples & Mean & Sd & Min & Max \\
\hline Tobin's Q & 5038 & 2.1304 & 1.0487 & 0.9905 & 6.8277 \\
ROA & 5038 & 0.059 & 0.046 & -0.102 & 0.191 \\
SHORT & 5038 & 0.509 & 0.500 & 0.000 & 1.000 \\
TREAT & 5038 & 0.326 & 0.463 & 0.000 & 1.000 \\
SHORT * TREAT & 5038 & 0.217 & 0.412 & 0.000 & 1.000 \\
CSR & 5038 & 25.284 & 14.926 & -16.720 & 89.010 \\
SIZE & 5038 & 22.803 & 0.786 & 20.959 & 24.781 \\
GROWTH & 5038 & 0.047 & 0.033 & 0.010 & 0.209 \\
LEV & 5038 & 0.3777 & 0.1763 & 0.0445 & 0.8017 \\
\hline
\end{tabular}

Table 5 presents Pearson's correlation matrix among variables. The short dummy (SHORT * TREAT) is positively correlated with both measures of firm financial performance, indicating short-selling deregulation move in the same direction of financial performance, though the coefficients are only 0.0688 and 0.0302 , representing only a weak correlation. It could be observed that CSR performance is positively correlated with Tobin's Q, ROA, and short-selling deregulation. Meanwhile, firm size and growth positively correlate with firm financial performance, short-selling deregulation, and CSR, whereas firm leverage has a negative association with all of them. 
Table 5. Pearson's correlation matrix.

\begin{tabular}{|c|c|c|c|c|c|c|c|c|}
\hline & Tobin's Q & ROA & SHORT & SHORT ${ }^{*}$ TREAT & CSR & SIZE & GROWTH & LEV \\
\hline Tobin's Q & 1.0000 & & & & & & & \\
\hline ROA & $0.2726^{* * *}$ & 1.0000 & & & & & & \\
\hline SHORT & $0.0125 * *$ & $0.0175^{* *}$ & 1.0000 & & & & & \\
\hline $\begin{array}{l}\text { SHORT * } \\
\text { TREAT }\end{array}$ & $0.0688^{* * *}$ & $0.0302 * *$ & $0.5264^{* * *}$ & 1.0000 & & & & \\
\hline CSR & $0.0511^{* * *}$ & $0.3546^{* * *}$ & $0.0444^{* * *}$ & $0.0383^{* * *}$ & 1.0000 & & & \\
\hline SIZE & $0.2763^{* * *}$ & $0.3256^{* * *}$ & $-0.0182 *$ & $0.2382 * * *$ & $0.0943^{* * *}$ & 1.0000 & & \\
\hline GROWTH & $0.5678^{* * *}$ & $0.3569^{* * *}$ & $-0.0789^{* * *}$ & $-0.1011^{* * *}$ & $0.0323^{* *}$ & $0.4313^{* * *}$ & 1.0000 & \\
\hline LEV & $-0.2934^{* * *}$ & $-0.3072^{* * *}$ & $0.0342 * *$ & $0.0797^{* * *}$ & $-0.0853^{* * *}$ & $0.0772 * * *$ & $-0.0344^{* *}$ & 1.0000 \\
\hline
\end{tabular}

Note: ${ }^{*}, * * * *$ denote significance at the $10 \%$, the $5 \%$, and the $1 \%$, respectively.

Based on the three-step model by Baron and Kenny (1986), Table 6 demonstrates the regression models to test the hypotheses in this study. Model 1 illustrates findings that short-selling deregulation significantly improves financial performance proxied by Tobin's $\mathrm{Q}$ and ROA with a 1\% significant level, indicating that hypothesis 1 is supported (Wang and Zhang 2020). The results revealed that the appearance of short-selling could promote the better performance of listed SMEs in China, hence supporting the external monitoring view of the short-selling mechanism.

Table 6. Short-selling deregulation, CSR performance and financial performance.

\begin{tabular}{|c|c|c|c|c|c|}
\hline \multirow[b]{2}{*}{ Variables } & \multicolumn{2}{|c|}{ Model 1} & \multirow{2}{*}{$\begin{array}{c}\text { Model } 2 \\
\text { CSR }\end{array}$} & \multicolumn{2}{|c|}{ Model 3} \\
\hline & Tobin's Q & ROA & & Tobin's Q & ROA \\
\hline Intercept & $\begin{array}{l}1.0552 * * * \\
(0.0013)\end{array}$ & $\begin{array}{c}-0.2591^{* * *} \\
(0.0000)\end{array}$ & $\begin{array}{c}-16.4354 \text { ** } \\
(0.0221)\end{array}$ & $\begin{array}{l}1.1684^{* * *} \\
(0.0016)\end{array}$ & $\begin{array}{c}-0.2608^{* * *} \\
(0.0000)\end{array}$ \\
\hline SHORT & $\begin{array}{l}0.0098^{*} \\
(0.0648)\end{array}$ & $\begin{array}{c}0.0137^{* *} \\
(0.0251)\end{array}$ & $\begin{array}{c}0.0305^{* * * *} \\
(0.0064)\end{array}$ & $\begin{array}{l}0.0100 \text { * } \\
(0.0536)\end{array}$ & $\begin{array}{c}0.0143 * * \\
(0.0261)\end{array}$ \\
\hline TREAT & $\begin{array}{c}0.0539 * * * \\
(0.0055)\end{array}$ & $\begin{array}{c}0.0237^{* *} \\
(0.0165)\end{array}$ & $\begin{array}{c}0.2785^{* * *} \\
(0.0026)\end{array}$ & $\begin{array}{c}0.0549^{* * *} \\
(0.0056)\end{array}$ & $\begin{array}{l}0.0246^{* *} \\
(0.0171)\end{array}$ \\
\hline SHORT * & $0.3804^{* * *}$ & $0.0050^{* * *}$ & $0.7572 * *$ & 0.1679 & 0.0048 \\
\hline TREAT & $(0.0000)$ & $(0.0006)$ & $(0.0365)$ & $(0.1192)$ & $(0.1105)$ \\
\hline CSR & & & & $\begin{array}{l}0.0010^{* *} \\
(0.0348)\end{array}$ & $\begin{array}{c}0.0009^{* * *} \\
(0.0000)\end{array}$ \\
\hline SIZE & $\begin{array}{l}0.0260 * \\
(0.0873)\end{array}$ & $\begin{array}{c}0.0145^{* * *} \\
(0.0000)\end{array}$ & $\begin{array}{l}2.0751 * * * \\
(0.0000)\end{array}$ & $\begin{array}{l}0.0277^{*} \\
(0.0901)\end{array}$ & $\begin{array}{c}0.0133^{* * *} \\
(0.0000)\end{array}$ \\
\hline GROWTH & $\begin{array}{c}18.9028^{* * *} \\
(0.0000)\end{array}$ & $\begin{array}{c}0.3708^{* * *} \\
(0.0000)\end{array}$ & $\begin{array}{l}-5.5686 \\
(0.4107)\end{array}$ & $\begin{array}{c}17.9795^{* * *} \\
(0.0000)\end{array}$ & $\begin{array}{c}0.3337^{* * *} \\
(0.0000)\end{array}$ \\
\hline LEV & $\begin{array}{c}-1.6685^{* * *} \\
(0.0000)\end{array}$ & $\begin{array}{c}-0.0841^{* * *} \\
(0.0000)\end{array}$ & $\begin{array}{c}-8.8203^{* * * *} \\
(0.0000)\end{array}$ & $\begin{array}{c}-1.6655^{* * * *} \\
(0.0000)\end{array}$ & $\begin{array}{c}-0.0726^{* * *} \\
(0.0000)\end{array}$ \\
\hline Ind-fixed & yes & yes & yes & yes & yes \\
\hline Year-fixed & yes & yes & yes & yes & yes \\
\hline R-squared & 0.4236 & 0.2676 & 0.0177 & 0.4185 & 0.3481 \\
\hline $\begin{array}{c}\text { Adj } \\
\text { R-squared }\end{array}$ & 0.4291 & 0.2632 & 0.0171 & 0.4192 & 0.3513 \\
\hline F-statistics & 903.3398 & 463.2897 & 23.3832 & 1031.3358 & 647.0402 \\
\hline $\mathrm{N}$ & 5038 & 5038 & 5038 & 5038 & 5038 \\
\hline
\end{tabular}

Additionally, model 2 presents a result about whether short-selling deregulation positively influences CSR performance. The result is consistent with our expectation that the appearance of short-selling could benefit CSR as the coefficient of SHORT * TREAT in model 2 is positive and significant within $5 \%$ level. Therefore, the relaxation of short-selling constraints can cultivate social responsibility practices and performance of listed SMEs in China. 
Lastly, model 3 proposed aims to test the mediating effect of CSR performance on the relationship of short-selling deregulation and financial performance. As mentioned in the research design section, the mediating effect of CSR performance is valid as long as three requirements are met. The results in model 1 and model 2 show that SHORT * TREAT is significant in both regressions, fulfilling the first requirement. Model 3 presents that the coefficient of CSR is positive and significant, meeting the second requirement. The coefficients of SHORT * TREAT in model 3 are lower than those in model 1, satisfying the third requirement. As SHORT * TREAT in model 3 is insignificant, while the CSR is significant, which indicates that the mediating effect of CSR performance is full mediation based on the definition of Baron and Kenny (1986) and reflecting that CSR performance is a full transmission for short-selling deregulation to influence financial performance. Thus, hypothesis 2 is supported as the CSR performance act as the full mediation on the relationship between short-selling deregulation and financial performance of listed SMEs in China.

Overall, the empirical study illustrates three essential findings. The first is that the existence of short-selling can improve financial performance, consistent with literature indicating short-selling is an alternative for effective external corporate governance (Massa et al. 2015). The second finding is that short-selling deregulation enhances corporate social responsibility, which indicates that the threats of short-selling can force managers to adopt CSR practices (Wang and Zhang 2020). The third and most important finding is that, though the average CSR performance is low, mediating effect of CSR performance is proved to be the complete mediating effect from short-selling deregulation to the firm financial performance of listed SMEs in China.

\subsection{Further Analysis of Family Business Effect}

When considering the interplay of family ownership between short-selling deregulation, CSR performance, and financial performance, it is interesting to note whether the mediating effect of CSR is more pronounced for family businesses. Previous literature has demonstrated the monitoring role of family owners on corporate behavior and CSR performance. Lamb and Butler (2018) study of 153 Fortune 100-300 firms showed that in comparison to the negative effect of short-term institutional investors, family ownership or a family member CEO improves social responsibility performance and mitigates environmental concerns, consistent with the stewardship theory and the socioemotional theory. Similarly, Velte (2020) reviewed whether ownership structure has an impact on CSR performance and disclosure by reviewing 81 empirical studies. They found that a higher ratio of long-term institutional ownership benefits CSR results since long-term, sustainable, and active investors strengthen CSR performance and disclosure, which in turn encourages stakeholders to invest in the environmentally sound firm. That is, long-term orientation institutional investors' promotion of CSR eventually improves investment returns for investors (Erhemjamts and Huang 2019). In this regard, family ownership embodies longterm investors, who focus more on CSR performance than short-term shareholders. Thus, this paper further hypothesized that the mediating effect of CSR is more pronounced for family businesses than for non-family businesses.

When measuring family ownership, this paper adopted the insights of Leitterstorf and Rau (2014) by defining a family business as one with a founder whose family possesses more than $25 \%$ of total ownership. This measurement was also adopted by Zulfiqar et al. (2020) when they assessed family firms in China. This study split the sample into two groups based on whether the firm is a family business or a non-family business and continued to test the aforementioned regressions.

Table 7 demonstrates that the mediating effect of CSR exists in both family business and non-family business in the $1 \%$ and $10 \%$ significant level. The coefficient of CSR for family businesses is higher than that for non-family businesses in both financial performance measurements, namely Tobin's $Q$ and ROA. Consistent with our expectations, the mediating effect of CSR performance between the relationship of short-selling and financial 
performance is more obvious for the family business, indicating family business, which is in the list of short-selling, prefer to choose to adopt more CSR practices to defend the threats of short-sellers and improve firm financial performance.

Table 7. Moderating effect of family ownership.

\begin{tabular}{|c|c|c|c|c|c|c|c|c|}
\hline \multirow[b]{3}{*}{ Variables } & \multicolumn{4}{|c|}{ Tobin's Q } & \multicolumn{4}{|c|}{ ROA } \\
\hline & \multicolumn{2}{|c|}{ Family Owned } & \multicolumn{2}{|c|}{ Non-Family Owned } & \multicolumn{2}{|c|}{ Family Owned } & \multicolumn{2}{|c|}{ Non-Family Owned } \\
\hline & Coefficient & Probability & Coefficient & Probability & Coefficient & Probability & Coefficient & Probability \\
\hline Intercept & $4.0089^{* * *}$ & 0.0000 & $3.4903 * * *$ & 0.0026 & $-0.5950^{* * *}$ & 0.0000 & $-0.4049^{* * *}$ & 0.0001 \\
\hline SHORT & $0.0097 *$ & 0.0608 & 0.0096 * & 0.0686 & $0.0142^{* *}$ & 0.0259 & $0.0143^{* *}$ & 0.0261 \\
\hline TREAT & $0.0538 * * *$ & 0.0055 & $0.0530 * * *$ & 0.0054 & $0.0244^{* *}$ & 0.0170 & $0.0246^{* *}$ & 0.0171 \\
\hline SHORT * TREAT & 0.3093 & 0.2337 & 0.1304 & 0.7012 & -0.0037 & 0.8335 & 0.0547 & 0.1296 \\
\hline CSR & 0.0015 * & 0.0647 & $0.0008 *$ & 0.0535 & $0.0010^{* * *}$ & 0.0000 & $0.0009^{* * *}$ & 0.0000 \\
\hline SIZE & $-0.0755 *$ & 0.0601 & $-0.0856 *$ & 0.0919 & $0.0225 * * *$ & 0.0000 & $0.0130^{* * *}$ & 0.0001 \\
\hline GROWTH & $26.7907^{* * *}$ & 0.0000 & $33.7172 * * *$ & 0.0000 & $0.2311^{* * *}$ & 0.0004 & $0.2838^{* * *}$ & 0.0003 \\
\hline LEV & $-2.4589 * * *$ & 0.0000 & $-2.2797^{* * *}$ & 0.0000 & $-0.0929 * * *$ & 0.0000 & $-0.0846^{* * *}$ & 0.0000 \\
\hline Ind-fixed & yes & & yes & & yes & & yes & \\
\hline Year-fixed & yes & & yes & & yes & & yes & \\
\hline R-squared & 0.6953 & & 0.7690 & & 0.4388 & & 0.2959 & \\
\hline Adj R-squared & 0.6617 & & 0.7582 & & 0.4273 & & 0.3002 & \\
\hline F-statistics & 259.1580 & 0.0000 & 296.0042 & 0.0000 & 96.8428 & 0.0000 & 39.9757 & 0.0000 \\
\hline $\mathrm{N}$ & 640 & & 449 & & 640 & & 449 & \\
\hline
\end{tabular}

Note: ${ }^{*}, * * * *$ denote significance at the $10 \%$, the $5 \%$, and the $1 \%$, respectively.

\subsection{Further Analysis of Real Short-Selling Threats}

The degree of short interest ratio, which represents the short-selling propensity of investors, was explored in the mediation of CSR performance between short-selling deregulation and financial performance. Evidence suggests that, compared to ordinary investors, short-sellers have superior experience and skills in collecting and analyzing public and private information. Consequently, a high volume of short-selling trading offers vital signs of a firm's unfavorable risk and underperformance of the underlying stock price (Massa et al. 2015). Meng et al. (2017) further confirmed this with their analysis of Chinese firms from 2010 to 2014, which indicated that short-sellers have similar analytical abilities and skills to top financial analysts. Gao et al. (2018) considered United States examples and found that company insiders, such as senior managers, take advantage of short-sellers shorting position information to sell their shares, implying that short-sellers are even more well-informed than company insiders. Thus, when the short-interest ratio is high, firms may face negative events, which call for executives to take actions, such as CSR, to prevent further short-selling activities.

The results demonstrated that deregulation of short-selling improves firm performance. Thus, it is posited that when firms experience real short-selling activities, shortable firms tend to increase CSR practices to prevent short-sellers and enhance firm performance. This study thus divided the sample into two subsamples according to the median of short interest ratio and subsequently tested the above regressions. The short interest ratio was calculated as the number of stocks sold by short-sellers minus the number of stocks repaid, divided by the prior day's trading volume. The one-year average ratio was utilized for our analysis.

Table 8 illustrates the regression results in both high and low SIR representing subgroups with high and low real short-selling positions. The findings indicate that CSR is the mediator for the relationships in both high and low SIR. The coefficient of CSR for the high real short-selling position is higher than that for a low real short-selling position in both financial performance measurements, Tobin's $Q$ and ROA, respectively. The results indicate that the mediating effect of CSR performance between the relationship of shortselling deregulation and financial performance is more pronounced for the family business, indicating when firms experiencing a higher level of real short-selling, they prefer to adopt CSR practices to improve financial performance. 
Table 8. Moderating effect of real short-selling threats.

\begin{tabular}{|c|c|c|c|c|c|c|c|c|}
\hline \multirow[b]{3}{*}{ Variables } & \multicolumn{4}{|c|}{ Tobin's Q } & \multicolumn{4}{|c|}{ ROA } \\
\hline & \multicolumn{2}{|c|}{ High SIR } & \multicolumn{2}{|c|}{ Low SIR } & \multicolumn{2}{|c|}{ High SIR } & \multicolumn{2}{|c|}{ Low SIR } \\
\hline & Coefficient & Probability & Coefficient & Probability & Coefficient & Probability & Coefficient & Probability \\
\hline Intercept & $2.7812 * * *$ & 0.0016 & $4.6826^{* * *}$ & 0.0001 & $-0.3971^{* * *}$ & 0.0000 & $-0.4058^{* * *}$ & 0.0000 \\
\hline SHORT & $0.0099 *$ & 0.0532 & $0.0097 *$ & 0.0721 & $0.0144^{* *}$ & 0.0263 & $0.0142 * *$ & 0.0260 \\
\hline TREAT & $0.0547^{* * *}$ & 0.0056 & $0.0543 * * *$ & 0.0055 & $0.0248 * *$ & 0.0173 & $0.0245 * *$ & 0.0170 \\
\hline SHORT * TREAT & 0.2749 & 0.3168 & 0.1647 & 0.5910 & 0.0145 & 0.4707 & 0.0188 & 0.3146 \\
\hline CSR & $0.0012 * *$ & 0.0322 & $0.0007 *$ & 0.0620 & $0.0011^{* * *}$ & 0.0000 & $0.0008^{* * *}$ & 0.0000 \\
\hline SIZE & -0.0542 & 0.1785 & $-0.1139 * *$ & 0.0139 & $0.0204^{* * *}$ & 0.0000 & $0.0219 * * *$ & 0.0000 \\
\hline GROWTH & $26.7180^{* * *}$ & 0.0000 & $28.8178^{* * *}$ & 0.0000 & $0.3377^{* * *}$ & 0.0001 & $0.1828^{* * *}$ & 0.0053 \\
\hline LEV & $-2.0198^{* * *}$ & 0.0000 & $-2.4332^{* * *}$ & 0.0000 & $-0.0830^{* * *}$ & 0.0000 & $-0.0891^{* * *}$ & 0.0000 \\
\hline Ind-fixed & yes & & yes & & yes & & yes & \\
\hline Year-fixed & yes & & yes & & yes & & yes & \\
\hline R-squared & 0.7425 & & 0.6647 & & 0.3923 & & 0.3493 & \\
\hline Adj R-squared & 0.7139 & & 0.6982 & & 0.3980 & & 0.3436 & \\
\hline F-statistics & 281.2179 & 0.0000 & 251.2186 & 0.0000 & 73.5539 & 0.0000 & 58.5682 & 0.0000 \\
\hline $\mathrm{N}$ & 545 & & 545 & & 545 & & 545 & \\
\hline
\end{tabular}

Note: ${ }^{*}, * * * *$ denote significance at the $10 \%$, the $5 \%$, and the $1 \%$, respectively.

\subsection{Robustness Test}

In this section, the researcher employs two sets of alternative measures the financial performance as dependent variables and CSR performance as mediator. Specifically, PB and ROE are adopted to substitute Tobin's $Q$ and ROA to represent market-based performance and accounting-based performance, while CSR ranking (CSRr) is used to substitute CSR scores as a mediator from Hexun.Net Database. The CSR ranking is measured as A-C and D proxied as 3, 2, 1 and 0 . Table 9 presents the regression results. Following the three-step model of Baron and Kenny (1986), SHORT * TREAT is positive and significant in the model 4 and 5, indicating short-selling deregulation can improve PB and ROE. CSRr is significant in model 6, while SHORT * TREAT becomes insignificant with the injunction of CSRr, indicating that CSRr acts as a mediator in this model. The robust test is valid and consistent with the above analysis.

Table 9. Robust test of alternative proxies.

\begin{tabular}{|c|c|c|c|c|c|}
\hline \multirow[b]{2}{*}{ Variables } & \multicolumn{2}{|c|}{ Model 4} & \multirow{2}{*}{$\begin{array}{c}\text { Model } 5 \\
\text { CSRr }\end{array}$} & \multicolumn{2}{|c|}{ Model 6} \\
\hline & PB & ROE & & PB & ROE \\
\hline Intercept & $\begin{array}{c}-2.6156^{* * *} \\
(0.0000)\end{array}$ & $\begin{array}{c}-0.6108^{* * *} \\
(0.0000)\end{array}$ & $\begin{array}{c}0.7900 * * * \\
(0.0014)\end{array}$ & $\begin{array}{c}-2.6585^{* * *} \\
(0.0000)\end{array}$ & $\begin{array}{c}-0.5599 * * * \\
(0.0000)\end{array}$ \\
\hline SHORT & $\begin{array}{c}0.0684^{* * *} \\
(0.0049)\end{array}$ & $\begin{array}{l}0.0148^{* *} \\
(0.0160)\end{array}$ & $\begin{array}{l}0.0179 * \\
(0.0879)\end{array}$ & $\begin{array}{c}0.0664^{* * *} \\
(0.0047)\end{array}$ & $\begin{array}{l}0.0144^{* *} \\
(0.0157)\end{array}$ \\
\hline TREAT & $\begin{array}{c}0.0607^{* * *} \\
(0.0040)\end{array}$ & $\begin{array}{l}0.0039 * \\
(0.0561)\end{array}$ & $\begin{array}{c}0.1152 * * * \\
(0.0036)\end{array}$ & $\begin{array}{c}0.0588^{* * *} \\
(0.0039)\end{array}$ & $\begin{array}{l}0.0038 * \\
(0.0548)\end{array}$ \\
\hline SHORT * TREAT & $\begin{array}{c}0.0010 * * * \\
(0.0032)\end{array}$ & $\begin{array}{c}0.0095 * * * \\
(0.0001)\end{array}$ & $\begin{array}{l}0.2141 * * \\
(0.0374)\end{array}$ & $\begin{array}{c}0.0004 \\
(0.1949)\end{array}$ & $\begin{array}{c}0.0099 \\
(0.2313)\end{array}$ \\
\hline CSRr & & & & $\begin{array}{l}0.0008 * * \\
(0.0431)\end{array}$ & $\begin{array}{c}0.0015^{* * *} \\
(0.0000)\end{array}$ \\
\hline SIZE & $\begin{array}{c}0.1606^{* * *} \\
(0.0000)\end{array}$ & $\begin{array}{c}0.0241^{* * *} \\
(0.0000)\end{array}$ & $\begin{array}{c}0.0135 \\
(0.1923)\end{array}$ & $\begin{array}{c}0.1541 * * * \\
(0.0000)\end{array}$ & $\begin{array}{c}0.0249 * * * \\
(0.0000)\end{array}$ \\
\hline GROWTH & $\begin{array}{c}65.3481 * * * \\
(0.0000)\end{array}$ & $\begin{array}{c}0.5901 * * * \\
(0.0000)\end{array}$ & $\begin{array}{l}-0.0761 \\
(0.7729)\end{array}$ & $\begin{array}{c}67.5807^{* * *} \\
(0.0000)\end{array}$ & $\begin{array}{c}0.5890 * * * \\
(0.0000)\end{array}$ \\
\hline LEV & $\begin{array}{l}-0.1185 \\
(0.3133)\end{array}$ & $\begin{array}{l}0.0120 * * \\
(0.0495)\end{array}$ & $\begin{array}{l}-0.0021 \\
(0.9562)\end{array}$ & $\begin{array}{l}-0.0994 \\
(0.3463)\end{array}$ & $\begin{array}{c}0.0247^{* * *} \\
(0.0000)\end{array}$ \\
\hline Ind-fixed & yes & yes & yes & yes & yes \\
\hline Year-fixed & yes & yes & yes & yes & yes \\
\hline R-squared & 0.7337 & 0.2028 & 0.0324 & 0.7556 & 0.3119 \\
\hline Adj R-squared & 0.7712 & 0.2102 & 0.0313 & 0.7675 & 0.3108 \\
\hline F-statistics & 3930.2706 & 334.6904 & 1.1477 & 3180.6216 & 452.3354 \\
\hline $\mathrm{N}$ & 5038 & 5038 & 5038 & 5038 & 5038 \\
\hline
\end{tabular}

Note: ${ }^{*}, * *{ }^{* * *}$ denote significance at the $10 \%$, the $5 \%$, and the $1 \%$, respectively. 


\section{Conclusions}

This paper examines the effect of short-selling deregulation on the firm financial performance of listed SMEs in China from 2010 to 2019. By adopting the PSM-DID method, we find that short-selling ban lifting improves firm financial performance significantly in both Tobin's Q and ROA. Furthermore, we adopt the Baron and Kenny (1986) model and explore CSR performance's mediating effect as the channel by which relaxation of short-selling constraints affects firm financial performance. Our tests confirm that the removal of short-selling constraints induces SMEs in China to adopt more sustainable practices and achieve better CSR performance, which contributes to improved firm financial performance. In addition, we also document that the mediating effect of CSR performance between short-selling deregulation and firm financial performance in SMEs is more obvious on family business and firms facing a high degree of real short-selling attacks. The results indicate that family businesses and firms with weakness intend to conduct CSR practices to improve firm financial performance when short-selling is available after deregulation. Lastly, we also conduct a robustness test with alternative measurements of firm financial performance and CSR performance, which confirms our basic results.

Our empirical results indicate that short-selling deregulation is positive and beneficial for the financial market and corporate performance in China. Our paper demonstrates the novel insight that short-selling improves the firm financial performance of SMEs in China, which is consistent with prior literature that has presented that short-selling can act as an external corporate governance mechanism and positively affect corporate behaviors, such as innovation, tax avoidance, and earning management ( $\mathrm{Li}$ et al. 2019a; Luo et al. 2020; Rennekamp et al. 2019). Moreover, short-selling also motivates management executives to undertake CSR practices, mitigates managerial myopia and eventually improves financial performance, especially for weak corporate governance firms, such as family businesses and firms with higher real threats of short-selling.

The findings of this paper provide several potential implications for policymakers, entrepreneurs and stakeholders. First, from the perspective of policymakers, the government should make more effort to expand the scales of short-selling deregulation and encourage firms to undertake CSR activities, thus creating a better financial environment for improving SMEs' financial performance. Second, from the entrepreneur perspective, a higher degree of CSR performance can defend the potential threats of short-selling deregulation and improve firm financial performance, so firm executives shall invest and practice more CSR activities. Lastly, from the perspective of stakeholders and the public, it is essential to note that existing internal corporate governance practices may not bring the expected effect of preventing corporate executives and major shareholders from abusing their rights and powers on short-sighted activities. Therefore, the short-selling mechanism's availability is a viable alternative, which provides independent monitoring on the corporate sustainability of SMEs in China.

Author Contributions: Writing—original draft, W.M.; Writing-review \& editing, N.I.N.b.A.H. All authors have read and agreed to the published version of the manuscript.

Funding: This research received no external funding.

Data Availability Statement: The data of this study is available from the authors upon request.

Conflicts of Interest: The authors declare no conflict of interest.

\section{References}

Ali, Waris, Jedrzej George Frynas, and Zeeshan Mahmood. 2017. Determinants of Corporate Social Responsibility (CSR) Disclosure in Developed and Developing Countries: A Literature Review. Corporate Social Responsibility and Environmental Management 24: 273-94. [CrossRef]

Alshehhi, Ali, Haitham Nobanee, and Nilesh Khare. 2018. The impact of sustainability practices on corporate financial performance: Literature trends and future research potential. Sustainability 10: 494. [CrossRef]

Baron, Reuben M., and David A. Kenny. 1986. The moderator-mediator variable distinction in social psychological research: Conceptual, strategic, and statistical considerations. Journal of Personality and Social Psychology 51: 1173. [CrossRef] [PubMed] 
Birindelli, Giuliana, Paola Ferretti, Mariantonietta Intonti, and Antonia Patrizia Iannuzzi. 2015. On the drivers of corporate social responsibility in banks: Evidence from an ethical rating model. Journal of Management and Governance 19: 303-40. [CrossRef]

Brockman, Paul, Juan Luo, and Limin Xu. 2020. The impact of short-selling pressure on corporate employee relations. Journal of Corporate Finance 64: 101677. [CrossRef]

Caliendo, Marco, and Sabine Kopeinig. 2008. Some practical guidance for the implementation of propensity score matching. Journal of Economic Surveys 22: 31-72. [CrossRef]

Chen, Huili, Ying Chen, Bin Lin, and Yanchao Wang. 2019. Can short selling improve internal control? An empirical study based on the difference-in-differences model. Accounting \& Finance 58: 1233-59.

Chen, Jun, Huimin Li, and Dazhi Zheng. 2020a. The Impact of Margin-Trading and Short-Selling on Stock Price Efficiency-Evidence from the Fifth-Round Ban Lift in the Chinese Stock Market. The Chinese Economy 53: 265-84. [CrossRef]

Chen, Shenglan, Robin K. Chou, Xiaoling Liu, and Yuhui Wu. 2020b. Deregulation of short-selling constraints and cost of bank loans: Evidence from a quasi-natural experiment. Pacific Basin Finance Journal 64. [CrossRef]

Cheng, Shijun, Robert Felix, and Yijiang Zhao. 2019. Board interlock networks and informed short sales. Journal of Banking E Finance 98 : 198-211.

Cicea, Claudiu, Ion Popa, Corina Marinescu, and Simona Cătălina Ștefan. 2019. Determinants of SMEs' performance: Evidence from European countries. Economic Research-Ekonomska Istraživanja 32: 1602-20. [CrossRef]

Deng, Xiang, and Xiang Cheng. 2019. Can ESG Indices Improve the Enterprises' Stock Market Performance?-An Empirical Study from China. Sustainability 11: 4765.

Deng, Xiaohu, and Lei Gao. 2018. The monitoring of short selling: Evidence from China. Research in International Business and Finance 43: 68-78. [CrossRef]

Endrikat, Jan. 2016. Market Reactions to Corporate Environmental Performance Related Events: A Meta-analytic Consolidation of the Empirical Evidence. Journal of Business Ethics 138: 535-48. [CrossRef]

Erhemjamts, Otgontsetseg, and Kershen Huang. 2019. Institutional ownership horizon, corporate social responsibility and shareholder value. Journal of Business Research 105: 61-79. [CrossRef]

Fang, Vivian W., Allen H. Huang, and Jonathan M. Karpoff. 2016. Short selling and earnings management: A controlled experiment. The Journal of Finance 71: 1251-94. [CrossRef]

Gao, Xinghua, and Scott D. Julian. 2018. The Use of CSR to Insure Against Short Selling Downside Risk. Paper presented at the Academy of Management Proceedings, Chicago, IL, USA, July 9.

Gao, George, Qingzhong Ma, and David Ng. 2018. The informativeness of short sellers: An insider's perspective. China Finance Review International 8: 354-86. [CrossRef]

He, Jie, and Xuan Tian. 2016. Do Short Sellers Exacerbate or Mitigate Managerial Myopia? Evidence from Patenting Activities. Paper presented at the 2016 American Finance Association Meetings, San Francisco, September 15.

Hou, Deshuai, Qingbin Meng, Kai Zhang, and Kam C. Chan. 2019. Motives for corporate philanthropy propensity: Does short selling matter? International Review of Economics \& Finance 63: 24-36.

$\mathrm{Hu}$, Yuanyuan, Shouming Chen, Yuexin Shao, and Su Gao. 2018. CSR and firm value: Evidence from China. Sustainability $10: 4597$. [CrossRef]

Jiang, Haiyan, Ahsan Habib, and Mostafa Monzur Hasan. 2020. Short Selling: A Review of the Literature and Implications for Future Research. European Accounting Review. [CrossRef]

Kiriu, Takuya, and Masatoshi Nozaki. 2020. A Text Mining Model to Evaluate Firms' ESG Activities: An Application for Japanese Firms. Asia-Pacific Financial Markets 27: 621-32. [CrossRef]

Lamb, Nai H., and Frank C. Butler. 2018. The influence of family firms and institutional owners on corporate social responsibility performance. Business \& Society 57: 1374-406.

Leitterstorf, Max P., and Sabine B. Rau. 2014. Socioemotional wealth and IPO underpricing of family firms. Strategic Management Journal 35: 751-60. [CrossRef]

Li, Chuntao, Hongmei Xu, Liwei Wang, and Peng Zhou. 2019a. Short-selling and corporate innovation: Evidence from the Chinese market. China Journal of Accounting Studies 7: 293-316. [CrossRef]

Li, Jialong, Zulfiquer Ali Haider, Xianzhe Jin, and Wenlong Yuan. 2019b. Corporate controversy, social responsibility and market performance: International evidence. Journal of International Financial Markets, Institutions and Money 60: 1-18. [CrossRef]

Li, Rui, Jiahui Li, and Jinjian Yuan. 2017. Short-sale prohibitions, firm characteristics and stock returns: Evidence from Chinese market. China Finance Review International 7: 407-28. [CrossRef]

Lu, Louise Yi, Yu Yangxin, and Liandong Zhang. 2016. Short selling pressure and corporate social responsibility performance. Paper presented at the Sakura Luojia Accounting Symposium 2016, Wuhan, China, December 15-16. Available online: https: / /ink.library.smu.edu.sg/soa_research/1673 (accessed on 8 April 2021).

Luo, Jinbo, Xiaoran Ni, and Gary Gang Tian. 2020. Short selling and corporate tax avoidance: Insights from a financial constraint view. Pacific-Basin Finance Journal 61: 101323. [CrossRef]

Mai, Wenzhen, and Nik Intan Norhan Binti Abdul Hamid. 2020. Understanding the Effect of Short Selling Mechanism on Market Value of Pharmaceutical Industry in China Under Covid-19. Paper presented at the Basic \& Clinical Pharmacology\& Toxicology, Toronto, ON, Canada, June 26. 
Massa, Massimo, Bohui Zhang, and Hong Zhang. 2015. The invisible hand of short selling: Does short selling discipline earnings management? The Review of Financial Studies 28: 1701-36. [CrossRef]

Meng, Qingbin, Ying Li, Xuanyu Jiang, and Kam C. Chan. 2017. Informed or speculative trading? Evidence from short selling before star and non-star analysts' downgrade announcements in an emerging market. Journal of Empirical Finance 42: 240-55. [CrossRef]

Michna, Anna, and Roman Kmieciak. 2020. Open-Mindedness Culture, Knowledge-Sharing, Financial Performance, and Industry 4.0 in SMEs. Sustainability 12: 9041. [CrossRef]

Miller, Edward M. 1977. Risk, uncertainty, and divergence of opinion. The Journal of Finance 32: 1151-68. [CrossRef]

$\mathrm{Ni}$, Xiaoran, and Sirui Yin. 2020. The unintended real effects of short selling in an emerging market. Journal of Corporate Finance 64. [CrossRef]

Park, KoEunc. 2017. Earnings quality and short selling: Evidence from real earnings management in the United States. Journal of Business Finance \& Accounting 44: 1214-40.

Rahman, Anisur, Bakhtear Talukdar, and Rafiqul Bhuyan. 2020. Board independence and short selling. Finance Research Letters. [CrossRef]

Rajesh, R., and Chandrasekharan Rajendran. 2020. Relating Environmental, Social, and Governance scores and sustainability performances of firms: An empirical analysis. Business Strategy and the Environment 29: 1247-67. [CrossRef]

Rennekamp, Kristina, Kathy Rupar, and Nicholas Seybert. 2019. Short Selling Pressure, Reporting Transparency, and the Use of Real and Accruals Earnings Management to Meet Benchmarks. Journal of Behavioral Finance 21: 186-204. [CrossRef]

Rusinova, Vanya, and Georg Wernicke. 2019. Short Selling and Performance on Corporate Social Responsibility: Evidence from a Natural Experiment. Paper presented at the Academy of Management Proceedings, Boston, MA, USA, August 1.

Velte, Patrick. 2020. Institutional ownership, environmental, social, and governance performance and disclosure-A review on empirical quantitative research. Problems and Perspectives in Management 18: 282-306. [CrossRef]

Wang, Shuxun, and Dongyang Zhang. 2020. Short-selling restrictions and firms' environment responsibility. Research in International Business and Finance 54. [CrossRef]

Xu, Jian, Feng Liu, and Yue Shang. 2020. R\&D investment, ESG performance and green innovation performance: Evidence from China. Kybernetes 50: 737-56.

Zulfiqar, Muhammad, Khalid Hussain, Muhammad Usman Yousaf, Nadeem Sohail, and Sadeen Ghafoor. 2020. Moderating role of CEO compensation in lean innovation strategies of Chinese listed family firms. Corporate Governance (Bingley) 20: 887-902. [CrossRef] 